\title{
Relationship of Work Engagement and Quality of Work Life with Nurses Performance in Installations of General Regional Hospital Makassar
}

\author{
Rahel Novelin Simarmata ${ }^{1}$, Syahrir Pasinringi ${ }^{1}$, Yahya Thamrin ${ }^{2}$ \\ ${ }^{1}$ Department of Hospital Management, Faculty of Public Health, Hasanuddin University, \\ Indonesia \\ ${ }^{2}$ Department of Occupational Health and Safety, Faculty of Public Health, Hasanuddin \\ University, Indonesia
}

Received: October 17, 2020

Received in Revised: October 25, 2020

Accepted: October 28, 2020

\begin{abstract}
Performance is the work result in quality and quantity achieved by employees in carrying out their duties in accordance with the responsibilities assigned to them. The role of reliable and professional employees is very helpful in improving organizational performance. This study aims to analyze the relationship between Work Engagement and Quality of Work Life with the Performance of Nurses in Inpatient Services in Makassar City Hospital. This type of research is a quantitative study using an observational study with a cross-sectional study design. Sampling using stratified random sampling so that the sample in this study were nurses in the inpatient installation of Makassar City Hospital, totaling 167 respondents. The results showed that there is a relationship between Work Engagement based on the Vigor dimension, the Dedication dimension, the absorption dimension, and the nurse's performance. There is a relationship between Quality of Work Life and the performance of nurses in Makassar City Hospital. It is recommended that hospital management keep paying attention to work engagement, especially the Vigor dimension in order to increase the morale of nurses. Leaders need to know what their employees need so that employees can work according to organizational expectations, one of which is by providing motivation. implementing a culture of health in the work environment so as to create a safe working atmosphere, developing career path plans for nurses, and internalizing the values of good work culture to maintain a sense of pride in the institution.
\end{abstract}

Keywords: Work Engagement, Vigor, Dedication, Quality of Work Life, Nurse Performance

\section{Introduction}

Performance is the work result in quality and quantity achieved by employees in carrying out their duties in accordance with the responsibilities assigned to them. The role of reliable and professional employees is very helpful in improving organizational performance. The quality of employees who are still far from adequate will certainly affect the resulting achievements. To achieve optimal performance requires interaction and coordination designed to connect tasks, both individuals and groups in order to achieve organizational goals (Mangkunegara, 2012).

A study has shown that a pleasant work environment is essential to encourage the most productive employee performance levels. In daily interactions, between superiors and subordinates, various other assumptions and expectations emerge. When superiors and subordinates form their own set of assumptions and expectations that are often somewhat 
different, it is these differences that ultimately affect performance levels. If employee performance can be managed properly, it will improve employee performance and have a positive impact on productivity and vice versa (Rivai \& Basri, 2005). One of the most important factors for an individual at work is Work Engagement, which is a concept that can reflect that an individual has a strong passion, focus, and dedication in working at the company. The work bond involves employees fully or as a whole, either cognitively, or emotionally, because in employee engagement these two things are fully involved to form a meaningful relationship (Schaufeli, Salanova, Gonzales-Roma, \& Bakker, 2002).

Work Engagement is influenced by three factors in which two factors were stated by Bakker (2011), namely work resources (job resources) and personal resources (personal resources). Job resources are one of the extrinsic factors that employees get when they are at work. Job resources are related to performance feedback, autonomy, and learning opportunities. Fulfilling the needs of Job Resources and the quality of employees when working is closely related to Quality Of Work Life because it is an effort to meet the needs of employees to carry out their duties properly and efficiently while at work. Not only that, but the quality of work-life is also able to make employees feel comfortable with their work (Sinha, 2012). Furthermore, personal resource (personal resource) is a positive self-evaluation that is related to resilience and refers to an individual's sense of their ability to control and have a good impact on their environment (Hobfoll et al., 2003). Personal resources are aspects of the self and are generally associated with joy and the feeling that the self is able to manipulate, control, and have an impact on the environment according to their wishes and abilities (Demerouti et al, 2001). Quality of Work Life includes activities that exist within the company, which are directed to improve a working life condition that can arouse morale in carrying out tasks to achieve company goals (Cascio, 2006).

The performance of nurses at Makassar City Hospital in 2017 with an average of $75.70 \%$ with details of nursing care, namely dimensions of nursing assessment, nursing diagnosis, planning, nursing actions, evaluation, and nursing records from the 100\% PPNI (Indonesian National Nurse Association) standard.

Previous interviews were also obtained with the HR department, where some nurses seemed less enthusiastic about their work. For example, when they arrive in the workroom, they do not immediately prepare a schedule or agenda that must be completed on that day, often procrastinate work, chat about various things outside of work, are less enthusiastic about completing work and some end work and rush to go home. even though the time is not quite right yet, Even so, there are some employees who are enthusiastic in preparing themselves for the day, enthusiastic about completing their work, and during breaks, there are employees who are still struggling with work, or in other words, employees find it difficult to escape from the work they are facing.

Therefore, the researcher hopes to carry out further analysis regarding the variable work engagement and Quality of Work Life with the performance of nurses so that the hospital is able to provide quality health services.

\section{Methods}

This type of research is a quantitative study using an observational study with a Cross-Sectional Study approach. This research was conducted at the Makassar City Hospital. 
The population in this study were all nurses in the Inpatient Installation of the Makassar City Hospital. The research sample amounted to 167 people. The sampling technique in this study is the Stratified Random Sampling.

The instrument used in data collection was a questionnaire, regarding the independent variables in the form of work engagement and quality of work-life, while the dependent variable was the nurse performance variable.

Univariate analysis was conducted to obtain an overview of the research problem by describing each variable used in the study and the characteristics of the respondent. The univariate analysis consisted of descriptive analysis of the characteristics of the respondents, descriptive analysis of research variables, and analysis of crosstabulation between the characteristics of the respondents and the research variables. Bivariate analysis was carried out to see the relationship between two variables, namely between the independent variable and the dependent variable. The statistical test used was the Chi-Square test.

\section{Results and Discussion}

Table 1. Frequency Distribution of General Characteristics of Respondents at Makassar City Hospital

\begin{tabular}{|l|l|l|}
\hline Respondent Characteristics & Amount (n) & Percentage (\%) \\
\hline Sex & 11 & \\
Male & 156 & 6.6 \\
Female & & 93.4 \\
\hline Age (years) & 38 & \\
$20-35$ & 75 & 22.8 \\
$36-45$ & 54 & 44.9 \\
$45+$ & & 32.3 \\
\hline Education & 0 & \\
High School & 24 & 0.0 \\
Diploma & 110 & 14.4 \\
Bachelor & 33 & 65.9 \\
Others & & 19.8 \\
\hline Years of Service (years) & 73 & \\
3 - 4 & 73 & 43.7 \\
$5-6$ & 21 & 43.7 \\
6+ & & 12.6 \\
\hline Employment status & 99 & \\
Civil Servant & 68 & 59.3 \\
Others & $\mathbf{1 6 7}$ & 40.7 \\
\hline Total & & \\
\hline
\end{tabular}

Source: Primary Data, 2020

Table 1 shows the frequency distribution based on the characteristics of the sample at the study location. Most of the respondents at Makassar City Hospital are at the age level of 36-45 years (44.9\%). In terms of gender, most of the respondents were female, namely 156 respondents (93.4\%). Last education, namely S1 as many as 110 respondents $(65.9 \%)$ with a working period 
of 3-4 years, as many as 73 respondents $(43.7 \%)$ with civil servant status, namely 99 respondents $(59.3 \%)$.

Table 2. Frequency Distribution of Respondents Based on Research Variables at Makassar City Hospital

\begin{tabular}{|l|l|l|}
\hline Research Variable & Amount (n) & Percentage (\%) \\
\hline Quality of Work Life & & \\
High & 118 & 70.7 \\
Low & 49 & 29.3 \\
\hline Work Engagement & & \\
High & 90 & 53.9 \\
Low & 77 & 46.1 \\
\hline Kinerja Perawat & & \\
High & 125 & 74.9 \\
Low & 42 & 25.1 \\
\hline Vigor & & \\
High & 124 & 74.3 \\
Low & 43 & 25.7 \\
\hline Dedication & & \\
High & 120 & 71.9 \\
Low & 47 & 28.1 \\
\hline Absorption & & \\
High & 120 & 71.9 \\
Low & 47 & 28.1 \\
\hline Total & $\mathbf{1 6 7}$ & $\mathbf{1 0 0 . 0}$ \\
\hline
\end{tabular}

Source: Primary Data, 2020

Table 2 explains the percentage of respondents' assessment of the research variables. The results at the Makassar City Hospital show that 59.3\% states that the height for the work engagement variable, for the vigor dimension, $74.3 \%$ states height, the dedication dimension is $71.9 \%$ states high, the absorption dimension is $808 \%$ states high, the quality of work-life dimension is $71.9 \%$ stated high while for the nurse performance variable showed that $74.9 \%$ stated high.

Table 3. Effect of Work Engagement and Quality of work-life on the performance of nurses in the Inpatient Installation of the Makassar City Hospital

\begin{tabular}{|c|c|c|c|c|c|c|c|}
\hline \multirow{3}{*}{$\begin{array}{c}\text { Quality of Work } \\
\text { Life }\end{array}$} & \multicolumn{4}{|c|}{ Nurse Performance } & \multirow{2}{*}{\multicolumn{2}{|c|}{ Amount }} & \multirow{3}{*}{$p$} \\
\hline & \multicolumn{2}{|c|}{ High } & \multicolumn{2}{|c|}{ Low } & & & \\
\hline & $\mathbf{n}$ & $\%$ & $\mathbf{n}$ & $\%$ & $\mathbf{n}$ & $\%$ & \\
\hline High & 101 & 85.6 & 17 & 14.4 & 118 & 100.0 & \multirow{3}{*}{0.001} \\
\hline Low & 24 & 49.0 & 49 & 51.0 & 49 & 100.0 & \\
\hline Total & 125 & 74.9 & 42 & 25.1 & 167 & 100.0 & \\
\hline \multirow{3}{*}{$\begin{array}{c}\text { Work } \\
\text { Engagement }\end{array}$} & \multicolumn{4}{|c|}{ Nurse Performance } & \multirow{2}{*}{\multicolumn{2}{|c|}{ Amount }} & \multirow{3}{*}{$\mathbf{p}$} \\
\hline & \multicolumn{2}{|c|}{ High } & \multicolumn{2}{|c|}{ Low } & & & \\
\hline & $\mathbf{n}$ & $\%$ & $\mathbf{n}$ & $\%$ & $\mathbf{n}$ & $\%$ & \\
\hline High & 92 & 94.8 & 5 & 5.2 & 97 & 100.0 & 0.001 \\
\hline
\end{tabular}

Copyright (C) 2020, Journal of Asian Multicultural Research for Medical and Health Science Study, Under the license CC BY-SA 4.0 


\begin{tabular}{|l|l|l|l|l|l|l|l|}
\hline Low & 33 & 47.1 & 37 & 52.9 & 70 & 100.0 & \\
\cline { 1 - 6 } Total & 125 & 74.9 & 42 & 25.1 & 167 & 100.0 & \\
\hline
\end{tabular}

Source: Primary Data, 2020

Table 3 shows the relationship between the independent variable and the dependent variable. Based on the results of the analysis, it can be seen that the effect of work engagement and quality of work-life variables on the performance of nurses in the Inpatient Installation of Makassar City Hospital. The results of the bivariate analysis with the chi-square test show that there is a relationship between work engagement variables and the performance of nurses in Makassar City Hospital with a value of $\mathrm{p}=0.001<0.05$ and a value of $\mathrm{r}=0.782$, there is a relationship between work engagement variables in the Vigor dimension and the performance of nurses at Makassar City Hospital with p-value $=0.001<0.05$ and $r=0.782$, there is a relationship between the work engagement variable in the dedication dimension and the performance of nurses at Makassar City Hospital with a value of $p=0.001<0.05$ and a value of $r=0.782$, there is a relationship between work engagement variables in the dimension absorption with the performance of nurses at Makassar City Hospital with p-value $=0.001<0.05$ and $r=0.782$ and there is a relationship between quality of work-life and nurse performance at Makassar City Hospital with p-value = $0.001<0.05$ and $\mathrm{r}=0.782$.

Based on the results of the study, it is stated that work engagement and quality of work-life have a relationship with the performance of nurses in the Inpatient Installation of Makassar City Hospital with a p-value $(0.001)<0.05$. Work engagement is a person's mental state related to their work which is positive and full, which is marked by vigor, dedication, and absorption (Schaufeli et al., 2002). Vigor is characterized by high energy and mental resilience at work, the desire to invest in a job, and stay afloat despite difficulties.

Based on the statistical analysis carried out, it is known that Work Engagement is based on the Vigor dimension of the performance of nurses in Makassar City Hospital. A significant effect is also indicated by a significance value of 0.003 . Vigor involves a high level of energy and mental endurance at work. Vigor can be assessed from the enthusiasm shown by a person to do his job which can be seen from the high stamina and energy when working, the willingness to make serious efforts in doing work, as well as persistence and persistence in facing difficulties at work (Schaufeli \& Bakker, 2002).

This is in line with Dajani's (2015) research where the vigor dimension in work engagement positively affects employee performance. This is in line according to Robinson, et al. (2004) stated that the vigor dimension in work engagement is able to provide a good influence in improving employee performance. There is a positive relationship between employee engagement and employee performance where according to Lockwood (2007), the higher the level of an employee's engagement, the performance will increase.

Based on the statistical analysis carried out, it is known that Work Engagement is based on the dimension of dedication to the performance of nurses in Makassar City Hospital. A significant effect is also indicated by a significance value of 0.004 . Dedication refers to being involved in one's work and experiencing a sense of meaning, enthusiasm, and pride. Aspects of dedication include high involvement in work, and experiencing a sense of meaning, an enthusiasm which is characterized by showing interest in the work being done, and pride in work (Dicke et al., 2007). This is in line with Dajani's research (2015) where the dimension of dedication in work 
engagement positively affects employee performance. This is in line according to Robinson, et al. (2004) stated that the dimension of dedication in work engagement can have a good influence on improving employee performance.

Based on the statistical analysis carried out, it is known that Work Engagement is based on the absorption dimension of the nurse's performance in Makassar City Hospital. A significant relationship is also indicated by a significance value of 0.004 . Absorption refers to concentrating fully and deeply, being immersed in work where time passes quickly and difficulty separating from work, thus forgetting everything around it. People who score high on absorption usually feel good about work being occupied, feel immersed in work, and have difficulty separating from work. As a result, whatever is around him is forgotten and time seems to pass quickly. Conversely, people with low absorption scores do not feel interested and are not immersed in work, have no difficulty separating from work and they do not forget everything around them, including time (Schaufeli et al., 2002).

Based on the statistical analysis carried out, it is known that the quality of work-life with the performance of nurses in Makassar City Hospital. A significant effect is also indicated by a significance value of 0.001. According to Rivai (2004) for a company to be successful, employee engagement must be more than just a systematic approach, it must be part of the company culture and part of the management philosophy. The most common method used to improve the quality of work-life is employee engagement.

Sinha's (2012) research on Quality of Work Life resulted in the extraction of 3 factors from various organizational factors. Three factors emerge, namely a). relationship-sustenance orientation, b). futuristic and professional orientation. c). self deterministic and systemic orientation. The results show that these factors have an important role in the Quality of Work Life for employees and for developing the work-related quality of life. Chan and Wyatt's research in Srivastava (2007) states that employees who have high welfare if employees feel satisfied with their work and company because they feel the Quality of Work Life (QWL) positively in the workplace and its QWL affects their health and psychology.

This research is supported by the theory of Robbins (2013) which states that communication helps develop motivation by explaining to employees what to do, how they work well, and what to do to improve performance if it is below standard. Several studies that have been conducted, found that there is a direct positive relationship between communication and employee performance. Trijaya's research (2012) suggests that compensation, training, and communication have a significant effect on employee performance and the dominant variable is compensation. Hariyanti and Primawesri (2011) also stated that motivation and communication have a positive effect on employee performance through organizational commitment. Meanwhile, Rachmadi's research (2010) that motivation, participation, and communication have a significant effect on employee performance.

\section{Conclusion}

Based on the research results, the researcher formulated the following conclusions: There is a relationship between work engagement including its dimensions, namely vigor, dedication, absorption, and quality of work-life with the performance of nurses in the Inpatient Installation of Makassar City Hospital. It is recommended that hospital management pay attention to work engagement, especially the Vigor dimension in order to increase the morale of nurses. Leaders 
need to know what the employees need so that employees can work according to organizational expectations, one of which is by providing motivation, implementing a work environment health culture so as to create a safe working atmosphere, developing career path plans for nurses, and internalizing the values of good work culture to maintain a sense of pride in the institution.

\section{References}

Ali, F., Gon kim, W., Li, J., \& Jeon, H.-M. (2016). Make it delightful: Customers Experience, Satisfaction and Loyalty in Malaysian theme parks. Journal of Destination Marketing dan Management, 1-11.

Bea. (2017). Pengaruh Service Experience dan Perceived Value Terhadap Kepuasan Pasien pada Instalasi Rawat Inap di RSUD Kota Makassar. Tesis: Universitas Hasanuddin, Makassar.

Berry, L. L., Wall, E. a., \& Carbone, L. P. (2006). Service Clues and Customer Assessment of the Service Experience: Lessons from Marketing. Journal Academy of Management Perspectives, 20(2):43-57.

Bhandari, S. (2017). Customer Experience Clues in Services, Impact of on Physical Surroundings Customers and Employees. Journal Academy of Management Perspectives, 56(2):57-71.

Helkkula, anu.2011. Characterising the concept of service experience. Journal of Service Management, 22(3):367-389.

Kisang Ryu, Hye-Rin Lee, W. G. K. (2012). The influence of the quality of the physical environment, food, and service on restaurant image, customer perceived value, customer satisfaction, and behavioral intentions. International Journal of Contemporary Hospitality Management, 24(2):200-223.

Labbe D, Ferrage A, Rytz A, Pace J, Martin N. (2015). Pleasantness, emotions and perceptions induced by coffee beverage experience depend on the consumption motivation (hedonic or utilitarian). Journal Food Quality and Preference, 44:56-61.

Maklan, S., \& Klaus, P. (2011). Customer Experience: Are We Measuring the Right Thing. International Journal of Market Research, 53(6):1- 22.

Mattila, A. S., \& Enz, C. A. (2002). The role of emotions in service encounters. Journal of Service Research, 4(4): 268-277.

Schifferstein HNJ., Fenko A., Desmet PMA., Labbe D, Martin N. (2013). Influence of package design on the dynamics of multisensory and emotional food experience. Journal Food Quality and Preference, 27:18-25.

Srivastava, M., \& Kaul, D. (2014). Social interaction, convenience, and customer satisfaction: The mediating effect of customer experience. Journal of retailing and consumer services, 2(21):1028-1037.

Suprianto, S. (2010). Pemasaran Industri Jasa Kesehatan. Teas, K. R. (1993). Expectations, Performance, Evaluation, and Consumers' Perceptions of Quality. Journal of Marketing, 57(4):18-34. 
Suryadi, S. (2001). Model Manajemen Sumber Daya Manusia Indonesia, Asia dan Timur Jauh. Jakarta: Bumi Aksara.

Turkay, O., \& Sengul, S. (2014). Employee behaviors creating customer satisfaction: A comparative case study on service encounters at a hotel. International Journal of Market Research, 3(2):21-28.

Yulianti.(2017). Pengaruh Atmosfer Gerai dan Pelayanan Ritel terhadap Nilai Hedonik dan Pembelian Impulsif Pelanggan Matahari Department Store Duta Plaza di Denpasar. Jurnal Manajemen, Strategi Bisnis, dan Kewirausahaan, 6(2):139-149. 